\section{Timing of Benzyladenine and Dikegulac Sodium Application Affects Branching of Liners and Finished Herbaceous Perennial Plants}

\author{
Mara Grossman, John Freeborn, Holly Scoggins, and Joyce Latimer ${ }^{1}$ \\ Department of Horticulture, Virginia Tech, Blacksburg, VA 24061
}

Additional index words. BA, Configure, Augeo, Sedum spectabile 'Autumn Joy', Gaillardia aristata 'Gallo Red', Phlox paniculata 'Bright Eyes', Nepeta racemosa 'Walker's Low', Delosperma 'Table Mountain', Achillea 'Moonshine', growth regulators

Abstract. Foliar spray applications of plant growth regulators (PGRs) benzyladenine (BA) and dikegulac sodium (DS) on herbaceous perennial liners and transplants were evaluated to determine effects on branching and quality. PGRs were applied three times (main plot): liner ( $24 \mathrm{~h}$ after removal from mist), post-transplant (5 to 7 days after transplant), or both (applications at liner and post-transplant). PGRs (subplots) were applied at concentrations of 400,800 , or $1600 \mathrm{mg} \cdot \mathrm{L}^{-1} \mathrm{DS}$; $600 \mathrm{mg} \cdot \mathrm{L}^{-1} \mathrm{BA}$; or a combination of $400 \mathrm{mg} \cdot \mathrm{L}^{-1} \mathrm{DS}$ and $600 \mathrm{mg} \cdot \mathrm{L}^{-1} \mathrm{BA}(\mathrm{DS} / \mathrm{BA})$. All studies included an untreated control. Sedum spectabile 'Autumn Joy' treated with PGRs at both application times had a $100 \%$ increase in branching compared with either single application time. Applied post-transplant, $800 \mathrm{mg} \cdot \mathrm{L}^{-1} \mathrm{DS}, \mathrm{BA}$, or DS/BA increased branching. Applied at both times, all DS concentrations or BA tripled the number of lateral branches per plant, whereas DS/BA resulted in a 4-fold increase in number of branches. Sedum treated with $1600 \mathrm{mg} \cdot \mathrm{L}^{-1} \mathrm{DS}$ at liner, post-transplant, or both application times was shorter than controls; plants sprayed with $1600 \mathrm{mg} \cdot \mathrm{L}^{-1} \mathrm{DS}$ at both application times were stunted. Phytotoxicity (yellow, narrow leaves) was present in finished plants treated with 800 or $1600 \mathrm{mg} \cdot \mathrm{L}^{-1} \mathrm{DS}$ or DS/BA post-transplant or with $1600 \mathrm{mg} \cdot \mathrm{L}^{-1} \mathrm{DS}$ applied both times. Gaillardia aristata 'Gallo Red' treated with PGRs at both application times had increased branching compared with plants subjected to a single application. Number of branches was increased by liner application of $400 \mathrm{mg} \cdot \mathrm{L}^{-1} \mathrm{DS}$, post-transplant applications of DS/BA, or applications both times of BA or DS/BA, whereas applications both times of $1600 \mathrm{mg} \cdot \mathrm{L}^{-1} \mathrm{DS}$ decreased branching and caused stunting and chlorotic foliage. In application as liners or at both times, all PGRs except $400 \mathrm{mg} \cdot \mathrm{L}^{-1}$ DS caused 16- to 33 day delays in flowering. Branching of Phlox paniculata 'Bright Eyes' was unaffected by application time. Only Phlox treated with BA or $1600 \mathrm{mg} \cdot \mathrm{L}^{-1} \mathrm{DS}$ at both application times had increased branches, although plants treated with $1600 \mathrm{mg} \cdot \mathrm{L}^{-1} \mathrm{DS}$ were shorter than controls and had phytotoxicity in the form of narrow, yellow leaves. Nepeta racemosa 'Walker's Low' treated with PGRs post-transplant or both application times had more branches than plants treated with PGRs once as liners. Number of branches was increased with $B A$ or $800 \mathrm{mg} \cdot \mathrm{L}^{-1} \mathrm{DS}$ applied post-transplant or $1600 \mathrm{mg} \cdot \mathrm{L}^{-1} \mathrm{DS}$, BA, or DS/BA applied both times, but the plants treated with $1600 \mathrm{mg} \cdot \mathrm{L}^{-1} \mathrm{DS}$ were stunted and had yellow leaves. Neither BA nor DS affected branching in Delosperma 'Table Mountain'. Application time did not affect branching in Achillea 'Moonshine'; only both applications of BA increased the number of branches in Achillea, whereas either single application of $1600 \mathrm{mg} \cdot \mathrm{L}^{-1} \mathrm{DS}$ or both applications of $800 \mathrm{or} 1600 \mathrm{mg} \cdot \mathrm{L}^{-1}$ DS caused phytotoxicity and stunting. Chemical names used: $\mathrm{N}$-(phenylmethyl)-1Hpurine-6-amine [benzyladenine (BA)], sodium 2,3:4,6-bis-O-(1-methylethylidene)- $\alpha-L$ xylo-2-hexulofuranosonate (DS)

\footnotetext{
Received for publication 26 Dec. 2012. Accepted for publication 7 May 2013.

Partial funding for this project was provided by Fine Americas, Inc. and the Virginia Nursery and Landscape Association.

We thank Conrad Fafard, Inc., and Aris Horticulture, Inc. for their support of floriculture research at Virginia Tech.

Mention of a trademark, proprietary product, or vendor does not constitute a guarantee or warranty of the product by Virginia Tech and does not imply its approval to the exclusion of other products or vendors that also may be suitable.

${ }^{1}$ To whom reprint requests should be addressed; e-mail jlatime@vt.edu.
} herbaceous perennials control plant growth by using both cultural controls, including plant nutrition, light, and temperature, and chemical controls, i.e., PGRs (Albrecht and Tayama, 1992; Whipker et al., 2006). PGRs can increase branching and improve plant architecture in plants by releasing apical dominance and allowing dormant lateral buds to expand, which results in fuller, well-branched plants (Cline, 1991). However, using PGRs can be challenging, because plants respond in different ways to PGRs depending on species, cultivar, growing
To produce uniform plants, growers of conditions, and the PGR used (Gent and McAvoy, 2000).

BA, a synthetic cytokinin, is a PGR that increases branching when sprayed on ornamental plants (Latimer and Freeborn, 2008; Martin and Singletary, 1999). The number of branches doubled in Echinacea (L.) Moench 'White Swan' and 'Double Decker' treated with foliar sprays of 300 or $600 \mathrm{mg} \cdot \mathrm{L}^{-1} \mathrm{BA}$ at $\approx 2$ weeks after transplanting to quart-sized (1.1-L) pots (Latimer and Freeborn, 2008). Of 18 juvenile perennials treated with BA as a foliar spray at rates of 1000,2000 , or $4000 \mathrm{mg} \cdot \mathrm{L}^{-1}, 89 \%$ had an increase in the number of lateral branches, although no additional branching was seen in the higher two rates as compared with $1000 \mathrm{mg} \cdot \mathrm{L}^{-1}$ (Martin and Singletary, 1999). However, in this study, plants treated with higher rates were more compact and had decreased leaf size.

DS has been used as a chemical pinch to prevent elongation in woody plants as well as to increase branching in herbaceous plants. Banko and Stefani (1995) assessed the use of DS on container-grown woody ornamentals. Of the nine species they studied, DS effectively controlled growth in five, producing plants that were more compact and appeared to have denser shoot growth. When 3-yearold field-grown Lavandula $\times$ intermedia Emeric ex Loisel. 'Twickle Purple' plants were treated with $0.5 \%, 1.0 \%$, or $2.0 \%$ Atrinal (PBI Gordon, Kansas City, MO; containing 20\% DS), the numbers of vegetative shoots and inflorescences and oil yield increased significantly compared with controls (Porter and Shaw, 1983). Branching of Gaillardia aristata Pursh. 'Gallo Yellow' was increased by foliar sprays of 400 or $800 \mathrm{mg} \cdot \mathrm{L}^{-1} \mathrm{DS}$ (Latimer and Freeborn, 2010). However, not all species are responsive to treatment with DS; as referenced previously, Banko and Stefani (1995) found five species responded to DS out of nine studied.

PGRs are often applied after transplant, when plants are in active growth and have started to expand. Treating liners (rooted cuttings) before transplant can have significant benefits for growers including reduced time of application and reduced chemical cost. Grossman et al. (2012) reported increases in branching in four of five herbaceous perennials treated with BA before transplant; of these, only two had persistent increases in branching after plants grew to finished size. The question of when to apply growth regulators to achieve increased branching in finished plants is an important one for growers who want to grow out liners to finished, marketable plants. The objective of this study is to examine the effects of application time of DS, BA, or a combination of the two on the growth and branching of herbaceous perennial plants during liner production and grow out of finished plants.

\section{Materials and Methods}

Six herbaceous perennials were studied: Sedum spectabile Boreau 'Autumn Joy', Gaillardia aristata Pursh 'Gallo Red', Phlox paniculata L. 'Bright Eyes', Nepeta racemosa 
Lam. 'Walker's Low', Delosperma NE Br. 'Table Mountain', and Achillea L. 'Moonshine'. Plants arrived on 18 May 2011 (Sedum, Gaillardia, and Phlox) and 22 June 2011 (Nepeta, Delosperma, and Achillea) as unrooted cuttings, which were dipped for $10 \mathrm{sec}$ in $1500 \mathrm{mg} \cdot \mathrm{L}^{-1}$ indole-3-butyric acid (IBA) rooting hormone (Hortus IBA Water Soluble Salts 20\% IBA; Hortus USA Corp., New York, NY) as a basal dip and stuck into 72 size cell (height $5.71 \mathrm{~cm}$, volume $35.4 \mathrm{~mL}$ ) trays filled with a peatmoss media with pine bark, perlite, and vermiculite $(45 \%, 25 \%, 15 \%$, and $15 \%$, by volume, respectively; Fafard 3B; Conrad Fafard, Inc., Agawam, MA). Cuttings were allowed to root under intermittent mist with bottom heat at $22^{\circ} \mathrm{C}\left(72^{\circ} \mathrm{F}\right)$ for 2 to 3 weeks depending on the crop. Mist intervals were adjusted as needed and gradually reduced as cuttings formed roots. Cuttings received clear water under mist, but after removal from mist received $100 \mathrm{mg} \cdot \mathrm{L}^{-1}$ nitrogen with each irrigation using $20 \mathrm{~N}-4.4 \mathrm{P}-16.6 \mathrm{~K}$ Peters Professional General Purpose fertilizer (The Scotts Co. LLC, Marysville, OH). Irrigation was applied on an as-needed basis (when media was dry at the top of the cell, generally daily) by hand-watering.

Growth regulators were applied as foliar sprays to plants at three application times: liner (plants received a single application of PGR when roots from cuttings were evident on all four sides of the root ball, but liners were not fully rooted and ready for transplant), post-transplant plants received a single application of PGR 5 to $7 \mathrm{~d}$ after liners were transplanted to quart-sized (1.1-L) pots, or both (plants received two applications of PGR, the first at the liner application time and the second at the post-transplant application time). PGR application for the liner application time occurred after plants were removed from mist; this was between 7 and $26 \mathrm{~d}$ after sticking (DAS) depending on when the crop was sufficiently rooted, defined as when roots were evident on all four sides of the root ball but liners were not fully rooted and ready for transplant. This occurred at the following times: in Nepeta at 7 DAS, in Delosperma at 14 DAS, in Sedum at 18 DAS, in Achillea and Gaillardia at 21 DAS, and in Phlox at 26 DAS. Each plant species was conducted as a separate experiment and included an untreated control, DS (Augeo, 18\% dikegulac sodium; OHP, Inc., Mainland, PA) at $400 \mathrm{mg} \cdot \mathrm{L}^{-1}, 800 \mathrm{mg} \cdot \mathrm{L}^{-1}$, or $1600 \mathrm{mg} \cdot \mathrm{L}^{-1}$; BA (Configure, $2 \%$ benzyladenine; Fine Americas, Inc., Walnut Creek, CA) at $600 \mathrm{mg} \cdot \mathrm{L}^{-1}$; or a tank mix combination of $400 \mathrm{mg} \cdot \mathrm{L}^{-1} \mathrm{DS}$ and $600 \mathrm{mg} \cdot \mathrm{L}^{-1} \mathrm{BA}$ (DS/BA). Foliar sprays were applied with a $\mathrm{CO}_{2}$ backpack sprayer ( $\mathrm{R} \& \mathrm{D}$ Sprayers, Inc., Opelousas, LA) at $210 \mathrm{~mL} \cdot \mathrm{m}^{-2}$. Plants were grown in a double polyethylene greenhouse located in Blacksburg, VA (lat. $37.23^{\circ} \mathrm{N}$, long. $80.42^{\circ} \mathrm{W}$ ) from May through Sept. 2011. Greenhouse light levels averaged $17.1 \mathrm{~mol} \cdot \mathrm{m}^{-2} \cdot \mathrm{d}^{-1}$ and temperatures averaged $23.7^{\circ} \mathrm{C}$. The experimental setup was a split plot design with time of application as the main plot factor and growth regulator treatment as the subplot factor. Experimental units consisted of two plants in a two-cell pack with six replications of the experimental unit per treatment for each of three destructive harvests for each crop. For finished plants, eight plants were selected from the experimental units for growing out and evaluation.

Data were collected at 0 and at 2 or 3 weeks after initial treatment (WAIT) on individual plants in each experimental unit; at 2 to 3 WAIT, liners were finished, fully rooted, and ready to be transplanted (see "Results" for specific crops). Measurements included plant height measured from the top of the container to the top of the plant, average width, which was the average of the width measured at the widest point of the plant and again perpendicular to this point, number of branches, number of days to flower from date of sticking, shoot dry weight, and any evidence of phytotoxicity. Branches were counted if they were $2 \mathrm{~mm}$ long or longer. Based on growth habit, branches counted in Achillea were basal branches that had no secondary laterals and in Sedum, Gaillardia, Phlox, Nepeta, and Delosperma, leaders (primary branches with secondary lateral branches) and secondary lateral branches were counted. Shoot dry weights were determined after drying shoots at $66^{\circ} \mathrm{C}\left(150^{\circ} \mathrm{F}\right)$ for $48 \mathrm{~h}$. Number of days to flower, flower and bud dry weight, and flower stalk height were also collected as applicable. Phytotoxicity symptoms were visually observed and assessed as reducing marketability (severe) or not (mild). As a result of premature flowering, Gaillardia liners were cut back to $5 \mathrm{~cm}$ the day before the initial PGR application.

After data were collected at 2 or 3 WAIT, eight plants of each treatment were randomly selected from the remaining replications and potted into quart-sized plastic pots $(1.1 \mathrm{~L})$ filled with Fafard 3B medium. Five to $7 \mathrm{~d}$ after transplant, growth regulators were applied to liners for the post-transplant and both application times. Plants were grown out for a period of 3 to 5 additional weeks based on growth rate to assess application time and PGR effects on the finished plants. Data collected were the same as discussed for liners. Data were analyzed by analysis of variance $(P \leq 0.05$, Student's $t$ test) using JMP $® 9.0$ C 2010 SAS Institute Inc. (Cary, NC).

\section{Results}

In all plants, measurements taken at 0 WAIT indicated no significant differences between control plants and plants treated with PGRs in plant height, width, numbers of leaders and lateral or basal branches, or shoot dry weights (data not presented). Sedum and Delosperma liners finished at 3 WAIT; Gaillardia, Phlox, Nepeta, and Achillea finished at 2 WAIT. Gaillardia plants were finished at 8 WAIT; Achillea at 7 WAIT; Sedum, Phlox, and Delopserma at 6 WAIT; and Nepeta at 5 WAIT.

\section{Liners}

In finished liners, only one application of growth regulators had been applied; therefore, only the effects of growth regulators are discussed in liners, whereas in finished plants, the main plot effects of time of application as well as the subplot effects of growth regulator applications are examined.

Sedum spectabile 'Autumn Joy'. The number of leaders on finished liners was unaffected by any of the PGRs; however, all PGR applications resulted in a greater number of branches relative to control plants, especially BA or DS/BA (Table 1). Plants were shorter after treatment with $1600 \mathrm{mg} \cdot \mathrm{L}^{-1} \mathrm{DS}, \mathrm{BA}$, or $\mathrm{DS} / \mathrm{BA}$, whereas width was greater in plants treated with $400 \mathrm{mg} \cdot \mathrm{L}^{-1}$ DS or DS/BA compared with controls. Plants treated with $1600 \mathrm{mg} \cdot \mathrm{L}^{-1}$ DS had less shoot dry weight, whereas plants treated with BA had greater shoot dry weight than control plants. Phytotoxicity was noted in all liners treated with DS or BA in the form of puckered leaves; however, the phytotoxicity was moderate in nature and would not reduce the marketability of the liners.

Gaillardia aristata 'Gallo Red'. Application of BA or DS/BA increased the numbers of leaders and branches, whereas $1600 \mathrm{mg} \cdot \mathrm{L}^{-1}$ DS reduced the numbers of leaders and branches (Table 1). Plants treated with $1600 \mathrm{mg} \cdot \mathrm{L}^{-1} \mathrm{DS}$, $\mathrm{BA}$, or DS/BA were shorter than control plants. Width was not significantly different in PGRtreated plants compared with controls. Shoot dry weight was less with $1600 \mathrm{mg} \cdot \mathrm{L}^{-1} \mathrm{DS}$, whereas shoot dry weight was greater with BA or DS/BA relative to controls. There was no evidence of phytotoxicity in Gaillardia liners.

Phlox paniculata 'Bright Eyes'. The number of leaders of finished liners was unaffected by PGRs, although the number of branches was greater with $1600 \mathrm{mg} \cdot \mathrm{L}^{-1} \mathrm{DS}, \mathrm{BA}$, or DS/ BA relative to control plants (Table 1). Application of 800 or $1600 \mathrm{mg} \cdot \mathrm{L}^{-1} \mathrm{DS}$ resulted in shorter plants, whereas width was unaffected by PGRs. Compared with control plants, shoot dry weight was less with $1600 \mathrm{mg} \cdot \mathrm{L}^{-1} \mathrm{DS}$ and greater with $\mathrm{BA}$ or $\mathrm{DS} / \mathrm{BA}$. There was no evidence of phytotoxicity in Phlox liners.

Nepeta racemosa 'Walker's Low'. Compared with control plants, finished liners treated with $1600 \mathrm{mg} \cdot \mathrm{L}^{-1}$ DS had a greater number of leaders; plants treated with either 800 or $1600 \mathrm{mg} \cdot \mathrm{L}^{-1}$ DS had more branches (Table 1). Shorter plants resulted from application of $1600 \mathrm{mg} \cdot \mathrm{L}^{-1} \mathrm{DS}$. Width and shoot dry weight were unaffected by PGR application. Plants treated with $1600 \mathrm{mg} \cdot \mathrm{L}^{-1}$ DS had phytotoxicity in the form of yellow leaves; phytotoxicity was mild and would not have reduced marketability.

Delosperma 'Table Mountain'. Finished liners treated with BA or DS/BA had a greater number of leaders compared with controls (Table 1). Plants treated with $400 \mathrm{mg} \cdot \mathrm{L}^{-1} \mathrm{DS}$ had fewer branches than control liners. Height and width were unaffected by PGRs; however, shoot dry weight was less in plants treated with $800 \mathrm{mg} \cdot \mathrm{L}^{-1} \mathrm{DS}$, BA, or DS/BA. No phytotoxicity was noted in Delosperma liners.

Achillea 'Moonshine'. The number of basal branches, width, and shoot dry weight of finished liners were unaffected by PGRs (data not presented). Compared with control, height 
Table 1. Number of leaders, number of lateral branches, height, average width, and shoot dry weight of Sedum spectabile 'Autumn Joy', Gaillardia aristata 'Gallo Red', Phlox paniculata 'Bright Eyes', Nepeta racemosa 'Walker's Low', and Delosperma 'Table Mountain' finished liners at 2 or 3 weeks after initial treatment (WAIT) with dikegulac sodium (DS), benzyladenine (BA), or a combination of the two, $400 \mathrm{mg} \cdot \mathrm{L}^{-1}$ DS plus $600 \mathrm{mg} \cdot \mathrm{L}^{-1} \mathrm{BA}$ (DS/BA).

\begin{tabular}{|c|c|c|c|c|c|}
\hline $\mathrm{PGR}\left(\mathrm{mg} \cdot \mathrm{L}^{-1}\right)$ & No. of leaders & No. of branches & $\mathrm{Ht}(\mathrm{cm})$ & Avg width $(\mathrm{cm})$ & Shoot dry wt (mg) \\
\hline \multicolumn{6}{|c|}{ Sedum spectabile ‘Autumn Joy’3 WAIT } \\
\hline Control & 2.0 & $2.8 \mathrm{e}^{\mathrm{z}}$ & $13.6 \mathrm{a}$ & $9.5 \mathrm{bc}$ & $692 \mathrm{bc}$ \\
\hline 400 DS & 1.8 & $5.7 \mathrm{~d}$ & $13.0 \mathrm{abc}$ & $10.6 \mathrm{a}$ & $752 \mathrm{ab}$ \\
\hline 800 DS & 1.8 & $7.0 \mathrm{c}$ & $13.3 \mathrm{ab}$ & $8.9 \mathrm{c}$ & $627 \mathrm{~cd}$ \\
\hline 1600 DS & 1.5 & $9.5 \mathrm{~b}$ & $10.1 \mathrm{~d}$ & $9.3 \mathrm{c}$ & $583 \mathrm{~d}$ \\
\hline $600 \mathrm{BA}$ & 2.1 & $12.8 \mathrm{a}$ & $12.4 \mathrm{bc}$ & $10.1 \mathrm{ab}$ & $780 \mathrm{a}$ \\
\hline DS/BA & 1.8 & $13.4 \mathrm{a}$ & $12.3 \mathrm{c}$ & $10.7 \mathrm{a}$ & $723 \mathrm{ab}$ \\
\hline Significance & $\mathrm{NS}^{\mathrm{y}}$ & $* * * *$ & $* * * *$ & $* * *$ & $* * * *$ \\
\hline \multicolumn{6}{|c|}{ Gaillardia aristata 'Gallo Red' 2 WAIT } \\
\hline Control & $1.8 \mathrm{~b}$ & $4.8 \mathrm{~b}$ & $7.7 \mathrm{a}$ & 9.3 & $326 \mathrm{bc}$ \\
\hline 400 DS & $1.8 \mathrm{~b}$ & $5.7 \mathrm{~b}$ & $7.4 \mathrm{ab}$ & 10.3 & $341 \mathrm{ab}$ \\
\hline 800 DS & $1.6 \mathrm{bc}$ & $5.1 \mathrm{~b}$ & $7.6 \mathrm{ab}$ & 9.9 & $297 \mathrm{~cd}$ \\
\hline 1600 DS & $1.1 \mathrm{c}$ & $2.5 \mathrm{c}$ & $6.4 \mathrm{c}$ & 9.8 & $274 \mathrm{~d}$ \\
\hline $600 \mathrm{BA}$ & $3.3 \mathrm{a}$ & $8.7 \mathrm{a}$ & $6.8 \mathrm{bc}$ & 9.9 & $374 \mathrm{a}$ \\
\hline $\mathrm{DS} / \mathrm{BA}$ & $3.2 \mathrm{a}$ & $9.1 \mathrm{a}$ & $6.3 \mathrm{c}$ & 9.5 & $374 \mathrm{a}$ \\
\hline Significance & $* * * *$ & $* * * *$ & $* *$ & NS & $* * * *$ \\
\hline \multicolumn{6}{|c|}{ Phlox paniculata 'Bright Eyes' 2 WAIT } \\
\hline Control & 1 & $2.1 \mathrm{c}$ & $8.8 \mathrm{a}$ & 9.3 & $300 \mathrm{~b}$ \\
\hline 400 DS & 1 & $2.0 \mathrm{c}$ & $7.9 \mathrm{ab}$ & 9.0 & $298 \mathrm{~b}$ \\
\hline 800 DS & 1 & $2.7 \mathrm{bc}$ & $7.3 \mathrm{bc}$ & 9.1 & $274 \mathrm{bc}$ \\
\hline $1600 \mathrm{DS}$ & 1 & $4.5 \mathrm{a}$ & $6.2 \mathrm{c}$ & 9.3 & $262 \mathrm{c}$ \\
\hline $600 \mathrm{BA}$ & 1 & $3.8 \mathrm{ab}$ & $8.8 \mathrm{a}$ & 10.3 & $334 \mathrm{a}$ \\
\hline $\mathrm{DS} / \mathrm{BA}$ & 1 & $5.2 \mathrm{a}$ & $8.5 \mathrm{ab}$ & 10.2 & $340 \mathrm{a}$ \\
\hline Significance & NS & $* * *$ & $* *$ & NS & $* * * *$ \\
\hline \multicolumn{6}{|c|}{ Nepeta racemosa 'Walker's Low' 2 WAIT } \\
\hline Control & $1.0 \mathrm{~b}$ & $15.4 \mathrm{c}$ & $22.4 \mathrm{a}$ & 8.5 & 346 \\
\hline 400 DS & $1.0 \mathrm{~b}$ & $15.8 \mathrm{c}$ & $22.0 \mathrm{a}$ & 8.3 & 321 \\
\hline 800 DS & $1.3 \mathrm{~b}$ & $17.9 \mathrm{ab}$ & $21.8 \mathrm{a}$ & 8.8 & 350 \\
\hline $1600 \mathrm{DS}$ & $3.3 \mathrm{a}$ & $18.7 \mathrm{a}$ & $18.9 \mathrm{~b}$ & 8.6 & 325 \\
\hline $600 \mathrm{BA}$ & $1.0 \mathrm{~b}$ & $16.7 \mathrm{bc}$ & $22.8 \mathrm{a}$ & 8.8 & 387 \\
\hline DS/BA & $1.1 \mathrm{~b}$ & $17.3 \mathrm{abc}$ & $22.9 \mathrm{a}$ & 8.4 & 376 \\
\hline Significance & $* * * *$ & $* *$ & $* * * *$ & NS & NS \\
\hline \multicolumn{6}{|c|}{ Delosperma 'Table Mountain' 3 WAIT } \\
\hline Control & $1.8 \mathrm{c}$ & $15.2 \mathrm{ab}$ & 2.4 & 8.7 & $358 \mathrm{a}$ \\
\hline 400 DS & $2.1 \mathrm{abc}$ & $13.3 \mathrm{c}$ & 2.5 & 8.0 & $336 a b c$ \\
\hline 800 DS & $1.7 \mathrm{c}$ & $14.0 \mathrm{bc}$ & 2.5 & 7.9 & $318 \mathrm{bc}$ \\
\hline $1600 \mathrm{DS}$ & $1.9 \mathrm{bc}$ & $14.4 \mathrm{abc}$ & 2.9 & 8.1 & $348 \mathrm{ab}$ \\
\hline $600 \mathrm{BA}$ & $2.5 \mathrm{a}$ & $14.8 \mathrm{ab}$ & 2.5 & 7.4 & $312 \mathrm{c}$ \\
\hline DS/BA & $2.4 \mathrm{ab}$ & $15.6 \mathrm{a}$ & 2.8 & 8.1 & $314 \mathrm{bc}$ \\
\hline Significance & * & * & NS & NS & * \\
\hline
\end{tabular}

${ }^{2}$ Means within a column followed by the same letter are not significantly different (Student's $t$ test, $\mathrm{n}=6$ based on two subsamples).

$\mathrm{y}_{\mathrm{NS}}, *, * * * * *$, and $* * * *$ represent, nonsignificant, significant at $0.05,0.01,0.001$, and 0.0001 , respectively, for each treatment.

$\mathrm{PGR}=$ plant growth regulator .

was greater in liners treated with $\mathrm{BA}(8.0 \mathrm{~cm}$ in BA-treated plants compared with $7.2 \mathrm{~cm}$ in controls) and less with 800 or $1600 \mathrm{mg} \cdot \mathrm{L}^{-1} \mathrm{DS}$ (6.3 and $5.9 \mathrm{~cm}$, respectively, $P<0.05$ ). Plants treated with $1600 \mathrm{mg} \cdot \mathrm{L}^{-1}$ DS had yellowed leaves; this phytotoxicity would have reduced marketability of these liners.

\section{Finished plants}

In finished Sedum plants, PGR application at both times increased the numbers of leaders and branches compared with application once at either liner or post-transplant stage (Table 2). There was a significant interaction between application time and PGRs in both number of leaders and number of branches. Plants treated with PGRs only as liners were not different from controls in the measurements of leaders and branches. However, plants treated with BA or DS/BA at the post-transplant application time had more leaders than the controls. treated with DS or DS/BA at both application times were not as wide as controls. PGR application at the liner stage only did not affect shoot weight. Plants treated with DS posttransplant had less shoot dry weight than the controls. Plants treated with 800 or $1600 \mathrm{mg} \cdot \mathrm{L}^{-1}$ DS at both application times had less shoot dry weight than the controls, whereas plants treated with BA at the post-transplant application time had greater shoot dry weight. Phytotoxicity in the form of yellow leaves was noted in plants treated with 800 or $1600 \mathrm{mg} \cdot \mathrm{L}^{-1}$ DS or DS/BA at the post-transplant application time and in plants treated with 800 or $1600 \mathrm{mg} \cdot \mathrm{L}^{-1} \mathrm{DS}$ both times; yellow leaves were still evident in finished plants. The phytotoxicity in plants treated with 800 or $1600 \mathrm{mg} \cdot \mathrm{L}^{-1} \mathrm{DS}$ both times reduced their marketability. No plants flowered during the study, although all plants were in bud at 6 WAIT.

Applying PGRs at both application times to Sedum resulted in the greatest numbers of branches and leaders and the branches were more well developed. Both DS and BA were effective in increasing branches in liners and finished plants; however, higher rates of DS caused more compact growth and resulted in greater phytotoxicity.

Finished Gaillardia plants treated with PGRs both times had more leaders and branches than plants receiving a single application either at the liner or post-transplant application time (Table 3). There were significant interactions of application time and PGRs in both measurements. Plants treated once with BA at the liner application time had more leaders than the controls. Plants treated once with $1600 \mathrm{mg} \cdot \mathrm{L}^{-1}$ DS or BA at the post-transplant application time had fewer leaders. Plants treated with either BA or DS/BA at both times had more leaders than the controls, whereas plants treated with $1600 \mathrm{mg} \cdot \mathrm{L}^{-1} \mathrm{DS}$ at both times had fewer leaders. The number of branches was greater with $400 \mathrm{mg} \cdot \mathrm{L}^{-1} \mathrm{DS}$ applied at the liner application time, whereas the number of branches was fewer in plants treated with $1600 \mathrm{mg} \cdot \mathrm{L}^{-1}$ DS as liners. Although DS applied posttransplant had no effect on branching, application of DS/BA post-transplant increased the number of branches compared with controls. Plants treated with $1600 \mathrm{mg} \cdot \mathrm{L}^{-1}$ DS both times had fewer branches, whereas plants treated with BA or DS/BA both times had more branches than the controls.

Gaillardia plants treated with PGRs at posttransplant or both times were shorter and had less width and shoot dry weight compared with plants treated as liners (Table 3 ). Plants treated with $1600 \mathrm{mg} \cdot \mathrm{L}^{-1} \mathrm{DS}$ as liners or with 800 or $1600 \mathrm{mg} \cdot \mathrm{L}^{-1} \mathrm{DS}$ or with DS/BA post-transplant or both times were shorter than controls. Plants treated with $1600 \mathrm{mg} \cdot \mathrm{L}^{-1}$ DS both times were stunted and had yellow foliage compared with controls. Width was less with $1600 \mathrm{mg} \cdot \mathrm{L}^{-1} \mathrm{DS}$ applied as liners, with all post-transplant applications, and with all PGR treatments except BA at both application times. However, the greatest reductions in width were with $1600 \mathrm{mg} \cdot \mathrm{L}^{-1} \mathrm{DS}$ at any application time. Plants treated with $1600 \mathrm{mg} \cdot \mathrm{L}^{-1}$ DS as liners, with all PGRs except $400 \mathrm{mg} \cdot \mathrm{L}^{-1} \mathrm{DS}$ at post-transplant, and 


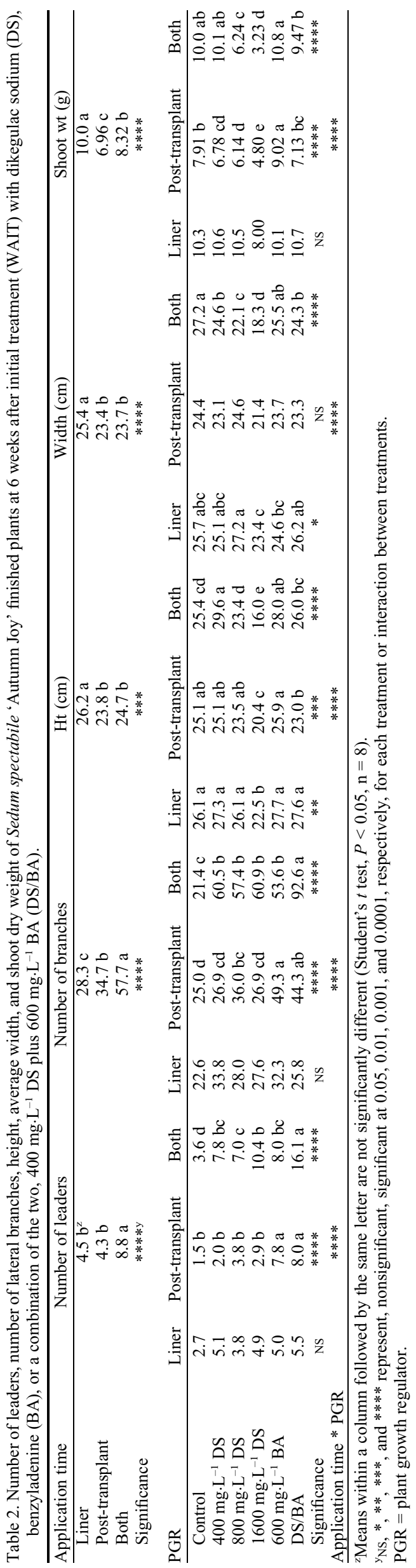

with 800 or $1600 \mathrm{mg} \cdot \mathrm{L}^{-1}$ DS both times had less shoot dry weight; plants treated with BA both times had greater shoot dry weight than the controls.

Days to first flower was delayed in Gaillardia treated with all PGRs as liners compared with post-transplant, whereas not all plants treated with PGRs both times flowered, resulting in a significant interaction between application time and PGRs (Table 4). Relative to control plants, plants treated with PGRs as liners had 16 to $33 \mathrm{~d}$ delays in flowering with all PGRs except $400 \mathrm{mg} \cdot \mathrm{L}^{-1} \mathrm{DS}$, whereas flowering was not delayed in plants treated with PGRs post-transplant. Flowering of plants treated with $800 \mathrm{mg} \cdot \mathrm{L}^{-1}$ DS both times was delayed $28 \mathrm{~d}$. Plants treated with $1600 \mathrm{mg} \cdot \mathrm{L}^{-1}$ DS, BA, or DS/BA both times did not flower during the study. Flower and bud dry weight of Gaillardia harvested at 8 WAIT was less in plants treated with PGRs post-transplant compared with those at the liner stage, whereas not all plants treated with PGRs at both times were budding or flowering; consequently, there was a significant interaction between application time and PGRs (Table 4). Flower and bud weight was less than that of controls in plants treated with 800 or $1600 \mathrm{mg} \cdot \mathrm{L}^{-1} \mathrm{DS}$ as liners, whereas flower and bud weight was greater than that of controls in plants treated with BA as liners. All finished plants treated with PGRs post-transplant or both times had less flower and bud weight compared with controls.

In Gaillardia, higher rates of DS had negative effects on plant growth; stunting and yellow foliage in plants treated with $1600 \mathrm{mg} \cdot \mathrm{L}^{-1} \mathrm{DS}$ both times reduced their marketability. BA and the low rate of DS led to more branches without reducing growth; however, delays in flowering may negate the positive effects of PGR application.

In finished Phlox plants, number of leaders was unaffected by application time or by PGRs (data not presented). Number of branches was unaffected by application time; however, there was an interaction between application time and PGRs (Table 5). The number of branches was unaffected by PGRs when applied once as liners or post-transplant, whereas plants treated with $1600 \mathrm{mg} \cdot \mathrm{L}^{-1}$ DS or BA both times had $91 \%$ or $57 \%$, respectively, more branches than control plants. Application time affected height; plants treated with PGRs both times were shorter compared with those treated post-transplant. Height was unaffected by PGRs. Width and shoot dry weight were unaffected by either application time or PGRs (data not presented). Days to flower was unaffected by application time, but there was a significant effect of PGRs; however, days to flower was not different in any of plants treated with PGRs compared with controls (Table 5). Flower and bud dry weight was unaffected by either application time or PGRs (data not presented). Flower stalk height was unaffected by application time; however, all PGRs except BA caused shorter flower stalk height compared with that of controls (Table 5). Although treatment with either $1600 \mathrm{mg} \cdot \mathrm{L}^{-1} \mathrm{DS}$ or BA both times increased branches, treatment with 


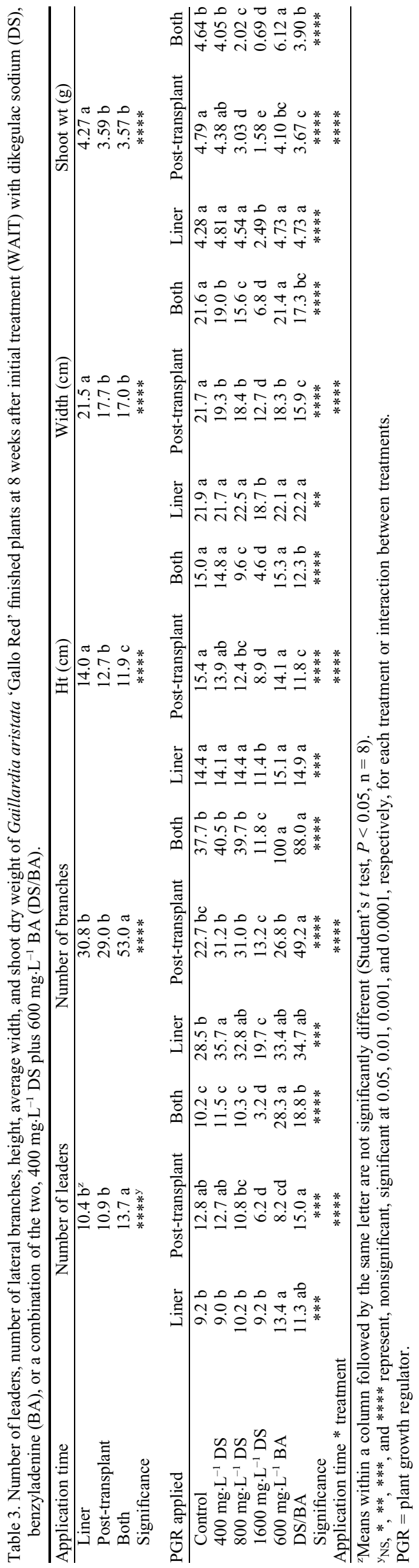

$1600 \mathrm{mg} \cdot \mathrm{L}^{-1} \mathrm{DS}$ caused significantly shorter flower stalk height as well as phytotoxicity in the form of yellowed, narrow foliage and thus reduced the marketability of finished plants.

Finished Nepeta plants treated with PGRs post-transplant or both times had more leaders than plants treated once as liners (Table 6). There was an interaction between application time and PGRs; there was no effect of PGRs applied at the liner stage on the number of leaders, whereas plants treated with $1600 \mathrm{mg} \cdot \mathrm{L}^{-1} \mathrm{DS}$ or BA post-transplant, or 800 or $1600 \mathrm{mg} \cdot \mathrm{L}^{-1} \mathrm{DS}$ or DS/BA both times, had two to 3.5 times the number of leaders as controls. Plants treated with PGRs post-transplant or both times also had more branches than plants with liner-only application. Application of $1600 \mathrm{mg} \cdot \mathrm{L}^{-1} \mathrm{DS}$ at the liner stage resulted in a reduction in number of branches. Plants treated with $800 \mathrm{mg} \cdot \mathrm{L}^{-1}$ DS or BA post-transplant or treated with $1600 \mathrm{mg} \cdot \mathrm{L}^{-1} \mathrm{DS}, \mathrm{BA}$, or DS/BA both times had more branches than control plants.

In addition to greater numbers of branches and leaders, Nepeta plants treated with PGRs post-transplant or both times were shorter and less wide than plants treated with PGRs as liners and there were significant interactions between application time and PGRs in both measurements. Plants treated with 400 or $1600 \mathrm{mg} \cdot \mathrm{L}^{-1} \mathrm{DS}$ as liners were shorter than controls. Application of 400 or $1600 \mathrm{mg} \cdot \mathrm{L}^{-1}$ DS or DS/BA post-transplant and application of $1600 \mathrm{mg} \cdot \mathrm{L}^{-1} \mathrm{DS}$ both times resulted in plants that were shorter than controls. Plants treated with $1600 \mathrm{mg} \cdot \mathrm{L}^{-1} \mathrm{DS}$ or BA as liners were not as wide as controls. Width was $54 \%$ or $18 \%$ less in plants treated with $1600 \mathrm{mg} \cdot \mathrm{L}^{-1}$ DS or DS/BA post-transplant, respectively. Plants treated with any PGR except DS/BA both times were not as wide as control plants. In Nepeta, $1600 \mathrm{mg} \cdot \mathrm{L}^{-1}$ DS applied at all application times resulted in stunted plants, which were $36 \%$ to $49 \%$ shorter and more compact ( $22 \%$ to $54 \%$ less width) than controls.

Nepeta treated with PGRs post-transplant or both times had less shoot dry weight compared with plants subjected to the liner stage application (Table 6). There was a significant interaction between application time and PGRs. Shoot dry weight of plants treated with PGRs as liners was not different from controls. Plants treated with $1600 \mathrm{mg} \cdot \mathrm{L}^{-1} \mathrm{DS}$ post-transplant or 800 or $1600 \mathrm{mg} \cdot \mathrm{L}^{-1} \mathrm{DS}$ both times had less shoot dry weight, whereas plants treated with BA both times had greater shoot dry weight. Days to first flower was not significantly affected by application time or PGR except that none of the plants that received $1600 \mathrm{mg} \cdot \mathrm{L}^{-1} \mathrm{DS}$ both times flowered during the study (data not presented). At 6 WAIT, phytotoxicity (yellow leaves) was noted in plants treated with 800 or $1600 \mathrm{mg} \cdot \mathrm{L}^{-1}$ DS both times. Although the effect of the yellow leaves was minor in plants treated with $800 \mathrm{DS}$, the yellow leaves were more evident in plants treated with $1600 \mathrm{mg} \cdot \mathrm{L}^{-1} \mathrm{DS}$. Treating Nepeta with $1600 \mathrm{mg} \cdot \mathrm{L}^{-1} \mathrm{DS}$ resulted in stunted plants with yellow leaves, which would not be marketable. 
Table 4. Days to first flower and flower and bud dry weight of Gaillardia aristata 'Gallo Red' finished plants at 8 weeks after initial treatment (WAIT) with dikegulac sodium (DS), benzyladenine (BA), or a combination of the two, $400 \mathrm{mg} \cdot \mathrm{L}^{-1}$ DS plus $600 \mathrm{mg} \cdot \mathrm{L}^{-1} \mathrm{BA}$ (DS/BA).

\begin{tabular}{|c|c|c|c|c|c|c|}
\hline Application time & \multicolumn{3}{|c|}{ Days to first flower ${ }^{z}$} & \multicolumn{3}{|c|}{ Flower and bud wt (g) } \\
\hline Liner & & 64.7 & & & 1.32 & \\
\hline Post-transplant & & 49.6 & & & 0.73 & \\
\hline Both & & $\mathrm{NA}^{\mathrm{y}}$ & & & $\mathrm{NA}^{\mathrm{v}}$ & \\
\hline Significance & & $* * * *^{\mathrm{x}}$ & & & $* * * *$ & \\
\hline PGR & Liner & Post-transplant & Both & Liner & Post-transplant & Both \\
\hline Control & $48.5 \mathrm{~d}^{\mathrm{w}}$ & 52.4 & $53.5 \mathrm{~b}$ & $1.52 \mathrm{bc}$ & $1.66 \mathrm{a}$ & $1.72 \mathrm{a}$ \\
\hline $400 \mathrm{mg} \cdot \mathrm{L}^{-1} \mathrm{DS}$ & $52.4 \mathrm{~d}$ & 48.3 & $47.9 \mathrm{~b}$ & $1.44 \mathrm{c}$ & $1.13 \mathrm{~b}$ & $1.04 \mathrm{~b}$ \\
\hline $800 \mathrm{mg} \cdot \mathrm{L}^{-1} \mathrm{DS}$ & $64.8 \mathrm{c}$ & 47.8 & $82.0 \mathrm{a}$ & $0.94 \mathrm{~d}$ & $0.39 \mathrm{~cd}$ & $0.09 \mathrm{~b}$ \\
\hline $1600 \mathrm{mg} \cdot \mathrm{L}^{-1} \mathrm{DS}$ & $82.0 \mathrm{a}$ & 49.0 & $\mathrm{NA}^{\mathrm{y}}$ & $0.28 \mathrm{e}$ & $0.22 \mathrm{~d}$ & $\mathrm{NA}^{\mathrm{v}}$ \\
\hline $600 \mathrm{mg} \cdot \mathrm{L}^{-1} \mathrm{BA}$ & $70.5 \mathrm{~b}$ & 50.5 & $\mathrm{NA}^{\mathrm{y}}$ & $1.98 \mathrm{a}$ & $0.56 \mathrm{c}$ & $0.14 \mathrm{c}^{\mathrm{u}}$ \\
\hline $\mathrm{DS} / \mathrm{BA}$ & $70.3 \mathrm{~b}$ & 50.0 & $\mathrm{NA}^{\mathrm{y}}$ & $1.77 \mathrm{ab}$ & $0.43 \mathrm{~cd}$ & $0.10 \mathrm{c}^{\mathrm{u}}$ \\
\hline Significance & $* * * *$ & NS & $* * *$ & $* * * *$ & $* * * *$ & $* * * *$ \\
\hline Application time * PGR & & $* * * *$ & & & $* * * *$ & \\
\hline
\end{tabular}

${ }^{\mathrm{z}}$ Days to first flower counted from time of sticking.

${ }^{\mathrm{y}} \mathrm{NA}=$ mean is not available because plants treated both times with $1600 \mathrm{mg} \cdot \mathrm{L}^{-1} \mathrm{DS}, \mathrm{BA}$, or DS/BA did not flower during the study.

${ }_{\mathrm{NSS}}^{*}, * *, * * *$, and $* * * *$ represent, nonsignificant, significant at $0.05,0.01,0.001$, and 0.0001 , respectively, for each treatment or interaction between treatments.

${ }^{\text {w}}$ Means within a column followed by the same letter are not significantly different (Student's $t$ test, $P<$ $0.05, \mathrm{n}=8)$.

${ }^{\mathrm{N} A}=$ mean is not available because plants treated both times with $1600 \mathrm{mg} \cdot \mathrm{L}^{-1} \mathrm{DS}$ had no flowers or buds. "At the end of the study, plants treated both times with BA or DS/BA had no open flowers but did have flower buds.

PGR $=$ plant growth regulator.

Table 5. Number of lateral branches, height, days to first flower, and flower stalk height of Phlox paniculata 'Bright Eyes' finished plants at 6 weeks after initial treatment (WAIT) with dikegulac sodium (DS), benzyladenine (BA), or a combination of the two, $400 \mathrm{mg} \cdot \mathrm{L}^{-1}$ DS plus $600 \mathrm{mg} \cdot \mathrm{L}^{-1} \mathrm{BA}$ (DS/BA).

\begin{tabular}{lcccc}
\hline Application time & No. of branches & $\mathrm{Ht}(\mathrm{cm})$ & $\begin{array}{c}\text { Days to } \\
\text { first flower }\end{array}$ & $\begin{array}{c}\text { Flower stalk } \\
\mathrm{ht}(\mathrm{cm})\end{array}$ \\
\hline Liner & 10.4 & $11.6 \mathrm{ab}$ & 56.5 & 17.1 \\
Post-transplant & 11.4 & $13.5 \mathrm{a}$ & 60.4 & 18.0 \\
Both & 11.4 & $10.3 \mathrm{~b}$ & 58.3 & 16.1 \\
Significance & $\mathrm{NS}^{\mathrm{y}}$ & $*$ & $\mathrm{NS}$ & $\mathrm{NS}$
\end{tabular}

\begin{tabular}{lcccccc} 
PGR & Liner & Post-transplant & Both & & & \\
\hline Control & 9.6 & 10.1 & $8.8 \mathrm{c}^{\mathrm{x}}$ & 12.9 & $59.6 \mathrm{ab}$ & $19.5 \mathrm{a}$ \\
$400 \mathrm{mg} \cdot \mathrm{L}^{-1} \mathrm{DS}$ & 9.4 & 11.8 & $7.6 \mathrm{c}$ & 10.7 & $55.8 \mathrm{~b}$ & $16.4 \mathrm{bc}$ \\
$800 \mathrm{mg} \cdot \mathrm{L}^{-1} \mathrm{DS}$ & 9.5 & 11.5 & $10.3 \mathrm{bc}$ & 10.9 & $57.9 \mathrm{ab}$ & $15.6 \mathrm{c}$ \\
$1600 \mathrm{mg} \cdot \mathrm{L}^{-1} \mathrm{DS}$ & 10.4 & 11.3 & $16.8 \mathrm{a}$ & 11.8 & $63.1 \mathrm{a}$ & $16.2 \mathrm{bc}$ \\
$600 \mathrm{mg} \cdot \mathrm{L}^{-1} \mathrm{BA}$ & 13.0 & 11.6 & $13.8 \mathrm{ab}$ & 14.0 & $62.3 \mathrm{a}$ & $18.9 \mathrm{ab}$ \\
DS/BA & 10.8 & 11.9 & $11.3 \mathrm{bc}$ & 10.5 & $53.9 \mathrm{~b}$ & $15.5 \mathrm{c}$ \\
Significance & NS & NS & $* * *$ & NS & $*$ & $*$ \\
Application time * PGR & & $*$ & & NS & NS & NS \\
\hline
\end{tabular}

${ }^{\mathrm{z}}$ Days to first flower counted from time of sticking.

$\mathrm{y}_{\mathrm{NS}}, *, * *, * * *$, and $* * * *$ represent, nonsignificant, significant at $0.05,0.01,0.001$, and 0.0001 , respectively, for each treatment or interaction between treatments.

${ }^{\mathrm{x}}$ Means within a column followed by the same letter are not significantly different (Student's $t$ test, $P<$ $0.05, \mathrm{n}=8$ )

$\mathrm{PGR}=$ plant growth regulator.

In finished Delosperma plants, there were no significant interactions between application time and PGRs (data not presented). Plants treated with PGRs post-transplant had fewer leaders and branches and less shoot dry weight compared with application either as liners or both times (data not presented). Width was greater in plants treated with PGRs as liners compared with post-transplant but not different from application at both times. Height and days to flower were unaffected by application time. Plants treated with PGRs had fewer branches than the controls; plants treated with PGRs other than $400 \mathrm{mg} \cdot \mathrm{L}^{-1} \mathrm{DS}$ had less shoot dry weight than the controls. Number of leaders, height, width, and days to flower were unaffected by PGRs. or post-transplant and with plants treated with 800 or $1600 \mathrm{mg} \cdot \mathrm{L}^{-1}$ DS both times.

\section{Discussion}

Timing of PGR application had a significant effect on the branching of four of the six crops tested. In all crops except Phlox and Achillea, applying PGRs both times, as liners and post-transplant, resulted in greater number of branches compared with one PGR application as liners only.

Sedum, Gaillardia, Phlox, Nepeta, and Achillea had significant interactions between time of application and PGR; treated with BA both times, these crops had more leaders and/ or branches than controls with no negative effects on plant growth overall as measured by height, width, or shoot dry weight. Likewise, multiple applications of BA increased shoot counts without having an effect on growth index in Nandina domestica Thunb. (Keever and Morrison, 2003). In petunias (Petunia Juss) treated with two applications of 80 or $160 \mathrm{mg} \cdot \mathrm{L}^{-1} \mathrm{BA}$ with the second application 3 weeks after the first, branching and flowering were increased and height was unaffected although diameter was reduced (Carey et al., 2008). Given that plants metabolize BA quickly, in $\approx 10 \mathrm{~d}$ (Carey et al., 2009), multiple applications over the production cycle may be more effective than a single application.

Two applications of the highest rate of DS led to reduced plant growth in all of the crops studied: Sedum, Nepeta, and Phlox treated with $1600 \mathrm{mg} \cdot \mathrm{L}^{-1}$ DS both times had more branches and reduced growth, Delosperma treated with $1600 \mathrm{mg} \cdot \mathrm{L}^{-1}$ DS both times had fewer branches, and Gaillardia and Achillea treated with $1600 \mathrm{mg} \cdot \mathrm{L}^{-1}$ DS both times had fewer branches and stunted growth. Similarly, two applications of DS (Atrimmec; PBI Gordon, Kansas City, MO) at concentrations of 1500 to $4500 \mathrm{mg} \cdot \mathrm{L}^{-1}$ applied 2 weeks after transplant and 6 weeks later stunted growth of Vinca minor L. (Keever et al., 2005). DS caused varying levels of phytotoxicity in Zinnia 'Scarlet Flame': concentrations of up to $500 \mathrm{mg} \cdot \mathrm{L}^{-1}$ resulted in yellow leaves, whereas concentrations over $750 \mathrm{mg} \cdot \mathrm{L}^{-1}$ caused more pronounced chlorosis and twisted leaves that lasted more than 2 weeks (Arzee et al., 1977). Concentrations of 800 to $3200 \mathrm{mg} \cdot \mathrm{L}^{-1}$ DS caused stunting and phytotoxicity in Gaillardia 'Gallo Yellow' finished plants 6 weeks after treatment, whereas $400 \mathrm{mg} \cdot \mathrm{L}^{-1}$ DS increased branches without negative growth effects (Latimer and Freeborn, 2010). In our experiment, two applications of $1600 \mathrm{mg} \cdot \mathrm{L}^{-1}$ DS had the effect of stunting growth and causing yellow foliage, which was evident in finished plants in all crops except Delosperma.

The application of DS/BA was effective at increasing the number of branches in four of six crops studied. In Sedum, two applications of DS/BA increased branches more than two applications of either BA or DS alone. In Gaillardia, Nepeta, and Achillea, DS/BA increased the number of branches as much as BA alone and more than DS alone. More 


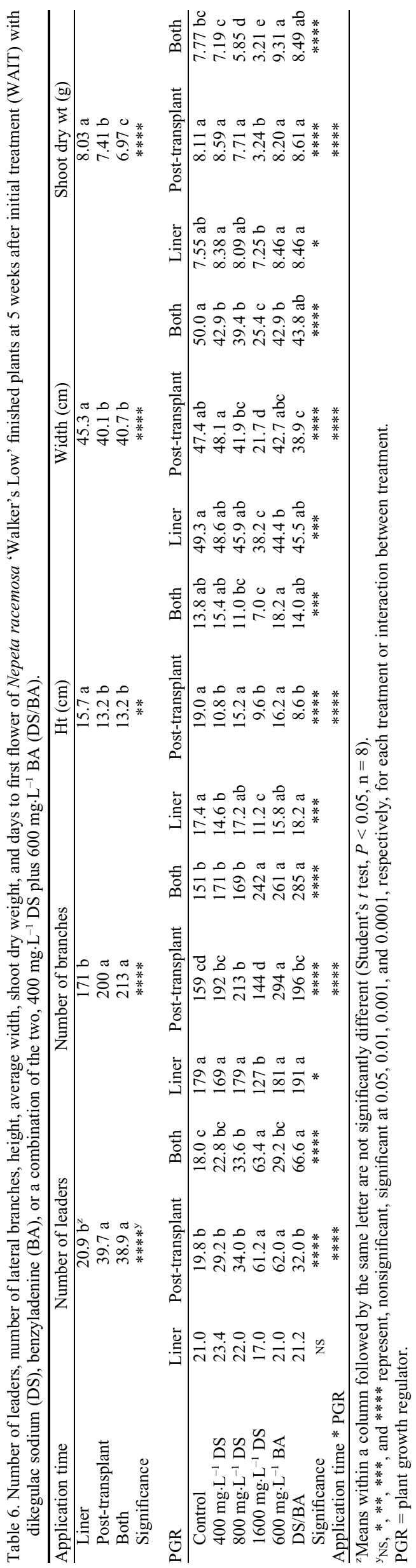

work will need to be done to examine if synergistic effects exist between BA and DS.

Both BA and DS applied as liners or at both times caused flower delay in Gaillardia; control plants flowered 54 DAS, whereas plants treated with $800 \mathrm{mg} \cdot \mathrm{L}^{-1}$ DS both times flowered 82 DAS and plants treated with $1600 \mathrm{mg} \cdot \mathrm{L}^{-1} \mathrm{DS}, \mathrm{BA}$, or DS/BA both times did not flower during the study. Nepeta treated at with $1600 \mathrm{mg} \cdot \mathrm{L}^{-1}$ DS both times did not flower during the 8-week study, whereas controls flowered at 41 DAS. Foliar sprays of 750 to $2250 \mathrm{mg} \cdot \mathrm{L}^{-1}$ DS increased the number of inflorescences in Kalanchoe $\times$ spp., although data were collected when all plants were flowering and days to flowering was not noted (Nightingale et al., 1985). Flowering was delayed $7 \mathrm{~d}$ in Coreopsis verticillata $\mathrm{L}$. 'Moonbeam' treated with 250 to $500 \mathrm{mg} \cdot \mathrm{L}^{-1} \mathrm{BA}$, whereas delays of up to $19 \mathrm{~d}$ and persistent chlorosis were seen in plants treated with 1000 to $2000 \mathrm{mg} \cdot \mathrm{L}^{-1} \mathrm{BA}$ (Farris et al., 2009). Flowering is an important feature in marketing plants; growers will need to consider possible delays of flowering when timing PGR applications to herbaceous perennials.

Applying BA or DS to herbaceous perennial liners before transplant increased branches in all species studied with higher rates of DS and BA being most effective in liners. However, after transplant and grow out to finished plants, high rates of DS reduced plant growth in most plants studied. Although a level of growth reduction is acceptable, the stunting seen with two applications of the highest rate of DS would reduce the marketability of plants. Two applications of PGRs were most effective in promoting branching resulting in long-term effects on the branching of finished plants.

\section{Literature Cited}

Albrecht, M.L. and H.K. Tayama. 1992. Tips on the use of chemical growth regulators on floriculture crops. Ohio Florists' Assoc., Columbus, $\mathrm{OH}$

Arzee, T., H. Langenauer, and J. Gressel. 1977. Effect of dikegulac, a new growth regulator, on apical growth and development of three Compositae. Bot. Gaz. 138:18-28.

Banko, T.J. and M.A. Stefani. 1995. Cutless and Atrimmec for controlling growth of woody landscape plants in containers. J. Environ. Hort. 13:22-26.

Carey, D., W. Buhler, and B. Whipker. 2009. Stimulating plant growth. Greenhouse Product News 9:20, 22, 24.

Carey, D., B. Whipker, I. McCall, and W. Buhler. 2008. Cytokinin based PGR affects growth of vegetative petunia. Proc. Plant Growth Regulat. Soc. Amer. 35:85-89.

Cline, M.G. 1991. Apical dominance. Bot. Rev. 57:318-358.

Farris, M.E., G.J. Keever, J.R. Kessler, and J.W. Olive. 2009. Benzyladenine and cyclanilide promote shoot development and flowering of 'Moonbeam' Coreopsis. J. Environ. Hort. 27:176-182.

Gent, M.P.N. and R.J. McAvoy. 2000. Plant growth retardants in ornamental horticulture: A critical appraisal, p. 89-130. In: Basra, A.S. (ed.). Plant growth regulators in agriculture and horticulture: Their role and commercial uses. Food Products Press, Binghamton. 
Grossman, M., J. Freeborn, H. Scoggins, and J. Latimer. 2012. Benzyladenine increases branching but reduces root growth of herbaceous perennial liners. HortScience 47:10851090.

Keever, G.J., J.B. Clark, and T.A. Morrison. 2005. Growth regulation of Vinca minor. J. Environ. Hort. 23:14-16.

Keever, G.J. and T.J. Morrison. 2003. Multiple benzyladenine applications increase shoot formation in Nandina. J. Environ. Hort. 21:144 147.
Latimer, J. and J. Freeborn. 2008. Enhance branching of Echinacea with PGRs. Greenhouse Product News 18:24-28.

Latimer, J.G. and J. Freeborn. 2010. Branching enhancers, Configure (6-BA) and Augeo (dikegulac sodium), affect branching of herbaceous perennials. Proc. Plant Growth Regulat. Soc. Amer. 37:148-152.

Martin, S. and S. Singletary. 1999. N-6 benzyladenine increases lateral offshoots in a number of perennial species. Proc. Intl. Plant Prop. Soc. 49:329-334.
Nightingale, A.E., S.E. Cross, and M.T. Longnecker. 1985. Dikegulac alters growth and flowering of Kalanchoe. HortScience 20:722-724.

Porter, N.G. and M.L. Shaw. 1983. Increasing growing points and oil yield in lavender by growth regulator sprays. J. Plant Growth Regul. 2:151-158.

Whipker, B.E., J.L. Gibson, and C.B. Cerveny. 2006. Rooting hormones and plant growth regulators, p. 89-100. In: Dole, J.M. and J.L. Gibson (eds.). Cutting propagation: A guide to propagating and producing floriculture crops. Ball Publishing, Batavia, IL. 